\title{
NURMET, ITALIAN RAIHEINÄ JA REHUKAALI TUOREREHUKASVEINA SUOVILJELYKSILLÄ
}

\author{
ERKKi PaUlamäki \\ Suoviljelysyhdistys, Leteensuon koeasema \\ ja \\ HEIKKI LUOSTARINEN \\ Suoviljelysyhdistys, Tohmajärven koeasema
}

Saapunut 17.8. 1970

\section{LEYS, ITALIAN RYEGRASS AND MARROW KALE AS FRESH FODDER CROPS ON CAREX PEAT}

ERккı Paulamäkı, Experiment Station at Leteensuo and

Heikki Luostarinen, Experiment Station at Tohmajärvi

\begin{abstract}
In 1967-1969 comparative experiments on ley crops and annual forage crops were arranged at the experiment stations of the Peat Cultivation Society at Leteensuo and Tohmajärvi. In the experiments two fertilizing intensities (LA1 = low and LA2 $=$ high) were used. Among other things these experiments on Carex peat gave the following results. Plant species determinations proved that in the meadow fescue-timothy ley the meadow fescue gained space from timothy. The red clover disappeared on the leys quickly and already in second year leys it was rare and was being replaced by meadow fescue.

The marrow kale gave the highest average fresh and dry matter yields. At both experiment stations the dry matter yield of the grass ley was lower than that of the marrow kale, but higher than that of the Italian ryegrass.

The Italian ryegrass had the highest crude protein content and the marrow kale the lowest. In the experiments at Tohmajärvi, the crude protein yields of the grass ley, Italian ryegrass and the marrow kale were the same as to the amount of yield, but at Leteensuo the crude protein yield of the Italian ryegrass was smaller than that of the other plants.

The dry matter content of forage diminished in the following order: ley crops, Italian ryegrass and marrow kale.

As silage the food unit and crude protein yields of the grass leys were higher than those of annual crops.
\end{abstract}

Nurmia ja monia yksivuotisia rehukasveja voidaan menestyksellisesti viljellä tuorerehun tuotantoa varten. Edullisissa oloissa saadaan sekä puna-apila- että heinäkasvinurmista korkeita satoja (RAININko 1968). Suoviljelyksillä puna-apilan viljely on kuitenkin epävarmempaa kuin kivennäismailla (PEssi 1966). Italian raiheinä ja rehukaali ovat monien tutkimusten mukaan arvokkaita yksivuotisia rehukasveja (ANTTINEN 1965, IsoTALO 1966, ANDERsson 1968 jne.), jotka menestyvät myös suoviljelyksillä. 
Seuraavassa vertaillaan heinäkasvinurmen ja puna-apilaa sisältävän nurmen sekä Italian raiheinän ja rehukaalin sadontuottokykyä suoviljelyksillä. Tulokset on saatu Suoviljelysyhdistyksen Leteensuon ja Tohmajärven koeasemilla v. 1967-69 järjestetyistä kokeista.

\section{Kokeiden järjestely}

Sekä Leteensuon että Tohmajärven koeasemien kokeet perustettiin metsäsaraturpeelle v. 1966, ja ensimmäiset koesadot saatiin seuraavana vuonna. Kokeet järjestettiin kaistoittain niin, että samalla kaistalla oli joko nurmikasveja tai yksivuotisia rehukasveja, jolloin yksivuotisten rehukasvien kaistat voitiin syksyllä kyntää.

Koejäseninä olivat nurminata-timoteinurmi, nurminata-puna-apilanurmi, Italian raiheinä ja rehukaali. Siemenmäärät olivat seuraavat: Italian raiheinä $30 \mathrm{~kg} / \mathrm{ha}$, rehukaali $7-10 \mathrm{~kg} / \mathrm{ha}$, nurminata-timotei $10+10 \mathrm{~kg} /$ ha ja nurminata-puna-apila $10+$ $7 \mathrm{~kg} / \mathrm{ha}$. Rivivälit olivat rehukaalilla $30 \mathrm{~cm}$ ja muilla kasveilla $15 \mathrm{~cm}$. Lannoitustasoja oli 2. Leteensuolla annettiin vuosittain 1. lannoitustasolla $600 \mathrm{~kg} / \mathrm{ha}$ PK-lannosta (16.5-16.5) ja 2. lannoitustasolla $1200 \mathrm{~kg} / \mathrm{ha} \mathrm{PK}$-lannosta ja $250 \mathrm{~kg} / \mathrm{ha}$ oulunsalpietaria $(25 \% \mathrm{~N})$ sekä molemmilla tasoilla $10 \mathrm{~kg} / \mathrm{ha}$ lannoiteboraattia. Tohmajärven kokeissa lannoitustaso 1 oli v. $19671000 \mathrm{~kg} / \mathrm{ha}$ ja lannoitustaso $22000 \mathrm{~kg} / \mathrm{ha}$ booripitoista Y-lannosta (6-13 - 12). V. 1968 lannoitukset olivat 500 ja $1000 \mathrm{~kg} /$ ha booripitoista super Y-lannosta (13-23-20) sekä v. 1969 lisäksi molemmissa tasoissa $250 \mathrm{~kg} /$ ha oulunsalpietaria. Kerranteita oli molemmissa lannoitustasoissa 4. Lannoituksista puolestaan oli 2 kerrannetta. Koeruudun koko oli $20 \mathrm{~m}^{2}$.

Nurminadan, timotein ja puna-apilan lajikkeena oli Tammisto molemmissa koepaikoissa. Italian raiheinän lajikkeina olivat yleensä Barmultra tai Tetrone. Rehukaalista käytettiin joko Escofar-lajiketta tai lajikkeeltaan tuntematonta kauppasiementä.

Rehukaali korjattiin kerran kesässä, Leteensuolla lokakuun alkupäivinä ja Tohmajärvellä syyskuun lopulla. Nurmet ja Italian raiheinä korjattiin 2-3 kertaa kesässä kasvustojen kehityksestä riippuen.

Nurmille ei tehty mitään hoitotoimenpiteitä. Vaikka rehukaalista käytettiin kuorrutettua siementä, eräinä vuosina jouduttiin suorittamaan ruiskutuksia tuhohyönteisiä vastaan. Alkukesällä rikkakasvit hävitettiin raiheinäkasvustoista MCPA-valmisteita käyttäen. Toisella ja kolmannella niittokerralla raiheinäkasvustot olivat rikkakasveista vapaita.

\section{Sääolot}

Taulukosta 1 nähdään koevuosien 1967-69 sääolot Leteensuolla ja Tohmajärvellä. Viimeistä kasvukautta lukuunottamatta alkukesän sademäärä oli Tohmajärvellä suurempi kuin Leteensuolla. Kesäkuukausien keskilämpötilat olivat puolestaan Leteensuolla selvästi korkeampia kuin Tohmajärvellä. Edullisemmista lämpöoloista johtuen typen mobilisaatio on Leteensuolla voimakkaampaa kuin Tohmajärvellä (vrt. Pessi 1966).

\section{Koetulokset}

Nurmien kasvilajikoostumusta seurattiin tekemällä kasvilajimäärityksiä niittokerroittain (taulukko 2). Esitetyt luvut ilmaisevat kunkin kasvilajin osuuden painoprosentteina tuoresadosta. Leteensuon koeasemalla oli koko ajan sama nurmi, joten eri vuosien tulokset 
Taulukko 1. Sääolot Leteensuolla ja Tohmajärvellä $1967-69$.

Table 1. Weather conditions at Leteensuo and Tohmajärvi 1967-69.

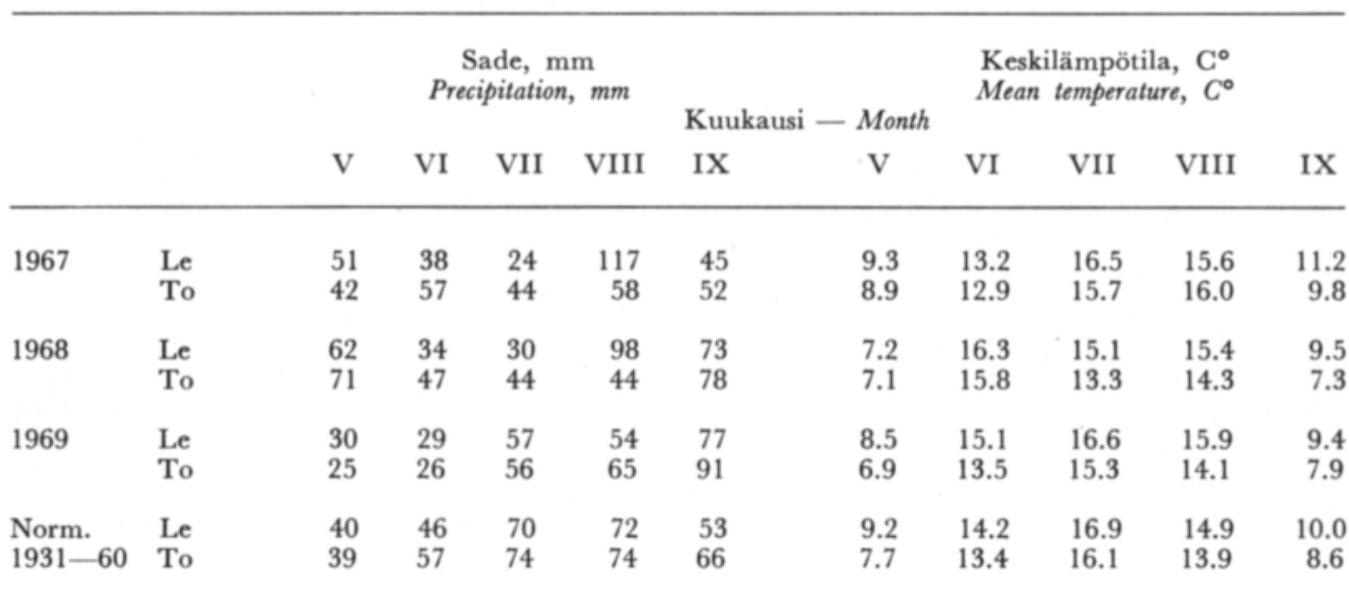

Tàulukko 2. Nurmien kasvilajikoostumus $1967-69, \%$.

Table 2. Botanical composition of leys 1967-69, \%.

\begin{tabular}{|c|c|c|c|c|c|c|c|c|c|c|}
\hline \multirow{5}{*}{\multicolumn{3}{|c|}{$\begin{array}{l}\text { Vuosi ja niittokerta } \\
\text { Year and number of cut }\end{array}$}} & \multicolumn{4}{|c|}{ LA 1} & \multicolumn{4}{|c|}{ LA 2} \\
\hline & & & \multirow{3}{*}{\multicolumn{2}{|c|}{$\begin{array}{l}\text { Nurminata- } \\
\text { timoteinurmi } \\
\text { Meadow fescue- } \\
\text { timothy ley }\end{array}$}} & \multirow{3}{*}{\multicolumn{2}{|c|}{$\begin{array}{l}\text { Nurminata- } \\
\text { puna-apilanurmi } \\
\text { Meadow fescue- } \\
\text { red clover ley }\end{array}$}} & \multirow{3}{*}{\multicolumn{2}{|c|}{$\begin{array}{l}\text { Nurminata- } \\
\text { timoteinurmi } \\
\text { Meadow fescue- } \\
\text { timothy ley }\end{array}$}} & \multirow{3}{*}{\multicolumn{2}{|c|}{$\begin{array}{l}\text { Nurminata- } \\
\text { puna-apilanurmi } \\
\text { Meadow fescue- } \\
\text { red clover ley }\end{array}$}} \\
\hline & & & & & & & & & & \\
\hline & & & & & & & & & & \\
\hline & & & $\mathrm{Fe}$ & $\mathrm{Ph}$ & $\mathrm{Fe}$ & $\mathrm{Tr}$ & $\mathrm{Fe}$ & $\mathrm{Ph}$ & $\mathrm{Fe}$ & $\mathrm{Tr}$ \\
\hline \multirow[t]{3}{*}{1967} & $\mathrm{Le}$ & 1 & 32 & 65 & 72 & 23 & 51 & 48 & 89 & 5 \\
\hline & & 2 & 41 & 48 & 70 & 25 & 48 & 50 & 84 & 15 \\
\hline & & 3 & 85 & 15 & 83 & 17 & 86 & 13 & 88 & 12 \\
\hline \multirow[t]{3}{*}{1968} & Le & 1 & 78 & 18 & 79 & 16 & 78 & 16 & 82 & 6 \\
\hline & & 2 & 89 & 9 & 89 & 9 & 81 & 16 & 97 & 2 \\
\hline & & 3 & 94 & 5 & 92 & 7 & 95 & 3 & 97 & 2 \\
\hline \multirow{3}{*}{1969} & Le & 1 & 73 & 8 & 67 & 4 & 60 & 16 & 66 & 0 \\
\hline & & 2 & 72 & 8 & 77 & i & 75 & 10 & 76 & 0 \\
\hline & & 3 & 84 & 2 & 83 & 1 & 80 & 1 & 90 & 0 \\
\hline \multirow[t]{2}{*}{1967} & To & 1 & 39 & 47 & 82 & 9 & 36 & 52 & 73 & 2 \\
\hline & & 2 & 60 & 37 & 77 & 22 & 54 & 44 & 79 & 9 \\
\hline \multirow[t]{2}{*}{1968} & To & 1 & 26 & 68 & 86 & 1 & 24 & 72 & 95 & 0 \\
\hline & & 2 & 57 & 36 & 94 & 2 & 52 & 42 & 99 & 0 \\
\hline \multirow[t]{3}{*}{1969} & To & 1 & 19 & 77 & 94 & 0 & 26 & 72 & 87 & 0 \\
\hline & & 2 & 37 & 51 & 78 & 0 & 56 & 40 & 93 & 0 \\
\hline & & 3 & 67 & 28 & 93 & 0 & 72 & 26 & 98 & 0 \\
\hline
\end{tabular}

ovat vertailukelpoisia keskenään. Sen sijaan Tohmajärven koeaseman tuloksia voidaan verrata vain vuosilta 1968 ja 1969, sillä ensimmäisen koevuoden tulos on eri kokeesta.

Timotein osuus oli nurminata-timoteinurmessa suurimmillaan alkukesällä, ja syksyä kohti nurminata valtasi kasvutilaa timoteilta paremman jälkikasvukykynsä ansiosta. 
Nurmen vanhetessa timotein osuus vähentyi erikoisen selvästi Leteensuon kokeissa. Myös RaININKo (1968) on saanut samansuuntaisia tuloksia.

Nurminata-puna-apilanurmessa apila säilyi paremmin alemmalla lannoitustasolla, mutta sen osuus oli jo toisen vuoden nurmissa varsin vähäinen. Tohmajärven kokeissa puna-apila katosi nurmista nopeammin kuin Leteensuolla. Puna-apilan viljely on mutasoilla selvästi epävarmempaa kuin heinäkasvinurmien viljely. Sen sijaan rahkasoilla punaapila menestyyy paremmin kuin mutasoilla (PESSI 1966).

Vuosina 1967 - 69 saadut keskimääräiset satotulokset on esitetty taulukossa 3. Rehukaali antoi korkeimman keskimääräisen tuore- ja kuiva-ainesadon molemmissa koepaikoissa. Tohmajärvellä nurminata-timoteinurmen sato oli suurempi kuin nurminatapuna-apilanurmen, mutta Leteensuolla molemmista nurmityypeistä saatiin käytännöllisesti katsoen samansuuruiset sadot. Italian raiheinä menestyi Tohmajärvellä suhteellisesti paremmin kuin Leteensuolla, missä se jäi selvästi heikkosatoisimmaksi. Ainakin osittain tämä johtui rikkakasvien hävittämisen epäonnistumisesta raiheinäkasvustosta Leteensuolla. Varsinkin v. 1969 esiintyi ensimmäisen niiton sadossa runsaasti ukontatarta.

Raakavalkuaissatojen osalta voidaan todeta, että nurmet ja rehukaali antoivat lannoitustasolla 2 keskimäärin samansuuruiset sadot. Raiheinä jäi Leteensuolla heikkosatoisimmaksi. Sen sijaan Tohmajärvellä raiheinän antama raakavalkuaissato oli jopa vähän suurempi kuin muiden kasvien.

Puna-apilaa sisältävän nurmen sato laski nurmen vanhetessa nopeammin kuin heinäkasvinurmen sato.

Taulukko 3. Keskimääräiset sadot $1967-69, \mathrm{~kg} / \mathrm{ha}$.

Table 3. The yields average $1967-69, \mathrm{~kg} / \mathrm{ha}$.

\begin{tabular}{|c|c|c|c|c|c|c|c|}
\hline & \multirow[t]{2}{*}{ LA } & \multicolumn{2}{|c|}{$\begin{array}{l}\text { Tuoresato } \\
\text { Fresh yield }\end{array}$} & \multicolumn{2}{|c|}{$\begin{array}{l}\text { Kuiva-ainesato } \\
\text { Dry matter yield }\end{array}$} & \multicolumn{2}{|c|}{$\begin{array}{l}\text { Raakavalkuaissato } \\
\text { Crude protein yield }\end{array}$} \\
\hline & & Le & To & Le & To & Le & To \\
\hline Nurminata - timotei & 1 & 39120 & 33170 & 7720 & 6720 & 1520 & 1000 \\
\hline Meadow fescue - timothy & 2 & 51830 & 44580 & 9490 & 8370 & 1780 & 1320 \\
\hline Nurminata - puna-apila & 1 & 45190 & 29680 & 8150 & 5970 & 1670 & 940 \\
\hline Meadow fescue-red clover & 2 & 51100 & 39770 & 9020 & 7350 & 1800 & 1180 \\
\hline Italian raiheinä & 1 & 38110 & 38460 & 5570 & 5840 & 1000 & 1170 \\
\hline Italian ryegrass & 2 & 44690 & 48430 & 6200 & 7010 & 1320 & 1430 \\
\hline Rehukaali & 1 & 64140 & 51870 & 8850 & 6720 & 1270 & 1070 \\
\hline Marrow kale & 2 & 85020 & 65800 & 11300 & 8550 & 1800 & 1350 \\
\hline
\end{tabular}

Nurmilta korjatun rehun kuiva-ainepitoisuudet olivat korkeammat kuin Italian raiheinän ja rehukaalin (taulukko 4). Tulosten suhteen on kuitenkin todettava, että kasvin kehitysaste vaikuttaa suuresti sadon laatuun.

\section{Säilöntätappioiden vaikutus}

Saadut satotulokset ja rehuanalyysit riittävät osoittamaan sadon käyttöarvoa oikeastaan vain silloin, kun ruokinta tapahtuu pellolta suoraan ilman varastointia. Eri kasvien 
Taulukko 4. Sadon laatu keskimäärin 1967-69.

Table 4. Quality of yield average 1967-69.

\begin{tabular}{|c|c|c|c|c|c|c|c|c|}
\hline & \multicolumn{2}{|c|}{$\begin{array}{l}\text { Nurminata- } \\
\text { timotei } \\
\text { Meadow fescue- } \\
\text { timothy }\end{array}$} & \multicolumn{2}{|c|}{$\begin{array}{c}\text { Nurminata- } \\
\text { puna-apila } \\
\text { Meadow fescue-red } \\
\text { clover }\end{array}$} & \multicolumn{2}{|c|}{$\begin{array}{l}\text { Italian raiheinä } \\
\text { Italian ryegrass }\end{array}$} & \multicolumn{2}{|c|}{$\begin{array}{l}\text { Rehukaali } \\
\text { Marrow kale }\end{array}$} \\
\hline & Le & To & Le & To & Le & To & Le & To \\
\hline & & & & L. & 2 & & & \\
\hline $\begin{array}{l}\text { Kuiva-aine, \% } \\
\text { Dry matter, \% }\end{array}$ & 18.4 & 18.8 & 17.9 & 18.5 & 14.6 & 14.5 & 13.2 & 13.0 \\
\hline $\begin{array}{l}\text { Raakavalkuainen, \% } \\
\text { Crude protein, \% }\end{array}$ & 18.1 & 15.8 & 19.5 & 16.1 & 21.3 & 20.4 & 15.9 & 16.3 \\
\hline $\begin{array}{l}\text { Tuhka, \% } \\
\text { Ash, \% }\end{array}$ & 9.9 & 8.8 & 9.8 & 9.1 & 12.7 & 9.8 & 14.8 & 11.8 \\
\hline $\begin{array}{l}\text { Raakarasva, \% } \\
\text { Raw fat, } \%\end{array}$ & 3.8 & 2.8 & 4.0 & 2.9 & 4.8 & 5.3 & 2.8 & 2.4 \\
\hline $\mathrm{Ca}, \%$ & 0.66 & 0.44 & 0.78 & 0.53 & 0.49 & 0.41 & 2.50 & 2.23 \\
\hline $\mathrm{P}, \%$ & 0.34 & 0.34 & 0.34 & 0.32 & 0.36 & 0.33 & 0.29 & 0.31 \\
\hline $\mathrm{Na}, \%$ & 0.028 & 0.017 & 0.025 & 0.015 & 0.076 & 0.024 & 0.067 & 0.027 \\
\hline
\end{tabular}

vertailua ajatellen on tärkeätä tietää myös se, millainen nettosato eri kasveista saadaan valmiina säilörehuna. Tällöin on säilöntätappioiden vaikutus otettava huomioon.

Monet tutkimukset osoittavat, että säilöntätappioiden suuruus riippuu säilöttävän rehun kuiva-ainepitoisuudesta niin, että mitä alhaisempi rehun kuiva-ainepitoisuus on, sitä suuremmat ovat säilöntätappiot (vrt. Linder ym. 1964, Hellberg 1966, Gross ja AvERDUNK 1968). Mainittuja lähteitä hyväksikäyttäen säilöntätappioiden suuruus arvioitiin seuraavasti:

\begin{tabular}{lcc} 
& \multicolumn{2}{c}{$\begin{array}{c}\text { Säilöntätappio \% } \\
\text { raakavalkuainen } \\
\end{array}$} \\
rehuyksiköt & 13 \\
Nurminata-timotei & 15 & 22 \\
Italian raiheinä & 25 & 35 \\
Rehukaali & 40 &
\end{tabular}

Korjuutappiot ja ruokintavaiheessa syntyvät tappiot arvioitiin samoiksi eri rehuille. Rehuyksikköjä laskettaessa käytettiin NJF:n rehutaulukoiden korvauslukuja ja sulavuuskertoimia.

Nurminata-timoteinurmi, Italian raiheinä ja rehukaali antoivat lannoitustasolla 2 seuraavat keskimääräiset tulokset:

\begin{tabular}{|c|c|c|c|c|c|}
\hline \multirow{3}{*}{$\begin{array}{l}\text { Nurminata-timotei } \\
\text { Italian raiheinä }\end{array}$} & \multirow{2}{*}{$\begin{array}{c}\begin{array}{c}\text { Ka-sato } \\
\text { kg/ha }\end{array} \\
8930\end{array}$} & \multirow{2}{*}{$\begin{array}{c}\begin{array}{c}\text { Ry-sato } \\
\mathrm{kg} / \mathrm{ha}\end{array} \\
6610\end{array}$} & \multirow{2}{*}{$\begin{array}{c}\begin{array}{c}\text { Rv-sato } \\
\text { kg/ha }\end{array} \\
1550\end{array}$} & \multicolumn{2}{|c|}{$\begin{array}{c}\text { Ry-sato Rv-sato } \\
\text { säilörehuna }\end{array}$} \\
\hline & & & & 5620 & 1350 \\
\hline & 6610 & 4720 & 1380 & 3540 & 1080 \\
\hline Rehukaali & 9930 & 7090 & 1580 & 4250 & 1030 \\
\hline
\end{tabular}

Rehukaalista saatiin siis suurin rehuyksikkösato ja Italian raiheinästä pienin. Raakavalkuaissadot olivat eri kasveilla suuruusluokaltaan samoja. Kun säilöntätappiot otetaan huomioon, nurmi voittaa niin rehuyksikkö- kuin raakavalkuaissadossakin rehukaalin ja raiheinän. 


\section{Ti ivistel $m \ddot{a}$}

Suoviljelysyhdistyksen Leteensuon ja Tohmajärven koeasemilla järjestettiin v. 196769 nurmien ja yksivuotisten rehukasvien vertailukokeita. Nämä metsäsaraturpeella järjestetyt kokeet antoivat mm. seuraavia tuloksia.

Kasvilajimääritykset osoittivat, että nurminata-timoteinurmessa nurminata valtasi kasvutilaa timoteilta. Puna-apila katosi nurmista nopeasti ja jo toisen vuoden nurmissa sen osuus oli vähäinen. Tilalle tuli nurminata.

Rehukaali tuotti suurimmat keskimääräiset tuore- ja kuiva-ainesadot. Heinäkasvinurmen kuiva-ainesato oli molemmissa koepaikoissa pienempi kuin rehukaalin, mutta suurempi kuin Italian raiheinän.

Italian raiheinällä oli korkein kuiva-aineen raakavalkuaispitoisuus ja rehukaalilla pienin. Tohmajärven kokeissa heinäkasvinurmen, Italian raiheinän ja rehukaalin raakavalkuaissadot olivat suuruusluokaltaan samoja, mutta Leteensuolla Italian raiheinän raakavalkuaissato jäi pienemmäksi kuin muiden kasvien.

Korjatun rehumassan kuiva-ainepitoisuus pieneni järjestyksessä nurmikasvit, Italian raiheinä ja rehukaali.

Heinäkasvinurmen antamat rehuyksikkö- ja raakavalkuaissadot olivat säilörehuksi laskettuna selvästi korkeammat kuin yksivuotisten kasvien.

\section{KIRJALLISUUS}

Andersson, S. 1968. Rajgräs i norra Sverige. Preliminärä resultat av försök med italienskt och westerwoldiskt rajgräs. Akt. Lantbr. högsk. 117: 1-34.

Antrinen, O. 1965. Pohjois-Suomen vihantarehukasveista. Summary: Comparative trials on various green fodder crops. Maatal. ja Koetoim. 19: 77-86.

Gross, G. \& Averdunk, G. 1968. Ưber die Trockensubstanzverluste beim Silieren eiweissreicher Futtermittel. Das wirtschaftseigene Futter 14, 3: 193-203.

Hellberg, A. 1966. Ensilerings och smältbarhetsförsök med baljväxtgrönfoder, grönraps och fodermärgkål, som skördats på olika tidpunkter. Lantbr. Högsk. Medd. A 66: 1-24.

Isotalo, A. 1966. Laiduntutkimuksia Perä-Pohjolassa. Summary: Development of pasture management in North Finland. Maatal. ja Koetoim. 20: 60-68.

Linder, H., Kvarnbäck, S., Persson, S. J., Henriksson, R., Edman, G. \& Wirell, C-A. 1964. Ekonomisk grovfoderhantering. Förs. och Forskn. 9-10:61-76.

Pessi, Y. 1966. Suon viljely. 139 p. Porvoo.

Raininko, K. 1968. The effects of nitrogen fertilization, irrigation and number of harvestings upon leys established with various seed mixtures. Acta Agr. Fenn. 112: 1-137. 